\title{
Estimates of fault strength from the Variscan foreland of the northern UK
}

\author{
Alex Copley ${ }^{1 *}$ and Nigel Woodcock ${ }^{2}$
}

1: COMET, Bullard Labs, Department of Earth Sciences, University of Cambridge, Cambridge, UK

2: Department of Earth Sciences, University of Cambridge, Cambridge, UK

* Email: acc41@cam.ac.uk

1 Abstract

2 We provide new insights into the long-standing debate regarding fault strength, 3 by studying structures active in the late Carboniferous in the foreland of 4 the Variscan Mountain range in the northern UK. We describe a method 5 to estimate the seismogenic thickness for ancient deformation zones, at the 6 time they were active, based upon the geometry of fault-bounded extensional 
7 basins. We then perform calculations to estimate the forces exerted between 8 mountain ranges and their adjacent lowlands in the presence of thermal and 9 compositional effects on the density. We combine these methods to calculate 10 an upper bound on the stresses that could be supported by faults in the 11 Variscan foreland before they began to slip. We find the faults had a low 12 effective coefficient of friction (i.e. $0.02-0.24$ ), and that the reactivated pre13 existing faults were at least $30 \%$ weaker than unfaulted rock. These results

16

${ }_{17} \quad$ Key words: Fault Strength, Variscan, Seismogenic thickness

\section{${ }_{19} 1$ Introduction}

20 The rheology of active faults is a major source of debate. A general issue ${ }_{21}$ concerns the magnitude of stresses that faults can support before breaking 22 in earthquakes, or undergoing creep at a significant rate. Previous studies ${ }_{23}$ have used a range of techniques to address this question, and have obtained 
a range of different results. The debate has often focused on estimating the coefficient of friction of faults (either the intrinsic value, or the effective coefficient of friction resulting from the combination of rock properties and pore fluid pressures). Hydro-fracturing in boreholes has been used to infer that the crust is cut by faults with an intrinsic coefficient of friction similar to that suggested by 'Byerlee's Law' (i.e. 0.6-0.8; (Byerlee, 1978)), and hydrostatic pore-fluid pressures (e.g. Brudy et al., 1997; Townend and Zoback, 2000). In contrast, some experiments on fault rocks cored by boreholes have resulted in much lower estimates of the intrinsic coefficient of friction (i.e. $\leq 0.3$; Lockner et al. (e.g. 2011); Ujiie et al. (e.g. 2013)). Geophysical arguments have been made that imply similarly low effective coefficients of friction (e.g. Lamb, 2006; Copley et al., 2011). The distribution of earthquake nodal plane dips has been interpreted as evidence for both high intrinsic coefficients of friction (e.g. 0.6; Sibson and Xie (1998); Collettini and Sibson (2001)), and also as an indicator of intrinsically low friction on fault planes [e.g. $\leq$ 0.3; Middleton and Copley (2014); Craig et al. (2014)]. The resolution of this debate has important implications for our understanding of lithosphere rheology, and also for assessing earthquake hazard. If fault friction is low, then earthquake stress-drops (commonly in the range of megapascals to tens 
43

44

45 on the fault plane, and significant time for stress build-up will be required

46

47

48

49

50

51

52

53

54

55

56

57

of megapascals (e.g. Kanamori and Anderson, 1975; Allmann and Shearer, 2009)) are likely to represent the majority of the pre-earthquake shear stress before earthquakes can nucleate again on a ruptured section of fault. If fault friction is high, then stress-drops in earthquakes will be only partial, and the timing of subsequent ruptures on a given fault could be highly variable. In view of the uncertainty regarding fault friction, this study aims to provide new information by studying the late Carboniferous deformation in the northern UK, in the foreland of the Variscan Mountain range. As part of this work, we outline how to estimate the seismogenic thickness in ancient deformation zones at the time they were active (by using a scaling between seismogenic thickness and basin geometry), and describe a method to calculate the force exerted between mountain ranges and their adjacent lowlands that takes into account thermal structures and chemical depletion. 
58

\section{The Variscan Foreland of the northern UK}

The Variscan Mountain range formed due to the collision between Gondwana and Laurussia, reached its maximum intensity in the late Carboniferous, and produced a Tibetan-scale orogenic belt covering central/southern Europe, and parts of northern Africa and North America. The range front of the northern margin of the Variscan Orogenic belt was just within the southern UK (Figure 1). Immediately south of this line, the Variscan Orogeny involved folding, cleavage formation, and low-grade metamorphism of sedimentary rocks (e.g. Woodcock and Strachan, 2012, and references therein).

The metamorphic grade increases southwards into northern France, and lateorogenic granites are common. Flexural foreland basin deposits are exposed in some locations, immediately to the north of the Variscan front (shown in blue on Figure 1). North of this flexural basin, many compressional structures were active in the foreland of the mountain range (e.g. Corfield et al., 1996; Warr, 2012). These faults and folds, most of which reactivate preexisting features, commonly underwent displacements of hundreds of metres to 1-2 km (e.g. Corfield et al., 1996; Woodcock and Rickards, 2003; Warr, 2012; Thomas and Woodcock, 2015). The deformation is analogous to the shortening observed in the forelands of modern orogenic belts, which occurs 
77 in response to the compressive force exerted between the mountains and the

78

79

80 adjacent lowlands (e.g. in the Himalayan foreland of India (e.g. Copley et al., 2011) and the Andean foreland of South America (e.g. Assumpcao, 1992)). In this paper we estimate an upper bound on the shear stresses required to make faults slip in the Variscan foreland, by resolving the total force exerted between the mountains and the lowlands onto the seismogenic layer in the region. This estimate is an upper bound for the stresses that were required to cause fault slip, because some of the total force could have been supported by the ductile lithosphere. Our calculations lead to insights into fault strength in addition to what has so far been achieved in the equivalent modern settings because of the detailed geological mapping that has been undertaken in the northern UK, which allows the geometry of the structures to be estimated. 
91

92

\section{Scaling between seismogenic thickness and}

extensional basin width

In order to estimate the seismogenic thickness during the late Carboniferous in the northern UK it is necessary to construct a method to infer this value from present-day observables. Previous studies have documented that the maximum widths of extensional basins bounded by normal faults are related to the depth extent of the faults (i.e. the seismogenic thickness) (e.g. Jackson and White, 1989; Scholz and Contreras, 1998). Deeper faults result in wider basins at the surface. Establishing the modern-day scaling between basin width and seismogenic thickness therefore provides a means to estimate the seismogenic thickness in ancient deformation belts in which basin widths can be observed or inferred. Figure 2 shows the relationship between maximum basin width and seismogenic thickness in modern-day extensional regions. The relationship between basin width and seismogenic thickness is clearly visible. The boxes encompass the range of maximum basin widths and seismogenic thicknesses for the fault systems in each region, estimated from published mapping, tectonic geomorphology, and local and teleseismic earthquake-source inversions (references given in the figure caption). We 
only use well-constrained earthquake depths, derived from the modelling of body-waveforms or recordings on dense local networks. The basin width is defined using the subsidence pattern resulting from motion on the presentlyactive basin-controlling fault (i.e. towards which the sediments in the basin interior dip). Older, inactive faults on the basin margins are not included in the measurements of basin width. As such, each measurement represents the width of basins produced by single, major, faults, and these may be embedded within a region that has experienced prior extension on older faults, or be currently also undergoing extension on other, spatially separated, structures.

Extensional basins formed in the early/mid Carboniferous, which predate the Variscan shortening in the northern UK, and are thought to represent back-arc extension before continent-continent collision, (e.g. Woodcock and Strachan, 2012). Post-Variscan extensional basins formed in the Permian and Triassic are thought to be related to post-orogenic collapse and intra-Pangaea rifting (e.g. Woodcock and Strachan, 2012). These pre- and post-Variscan basins show maximum widths of $20-30 \mathrm{~km}$ (e.g. the Carboniferous Northumberland Trough, Bowland and North Staffordshire Basins, and 
southern North Sea, and the Permian and Triassic North Minch and North Lewis Basins and Worcester Graben (Stein and Blundell, 1990; Chadwick et al., 1995; Corfield et al., 1996; Aitkenhead et al., 2002; Waters and Davies, 2006); labelled on figure 1). Although some sub-basins show smaller widths, modern-day analogues demonstrate that it is the maximum basin widths in a region that scale with the seismogenic thickness (as plotted on Figure 2). Basin widths of 20-30 km imply a seismogenic thickness of $15-40 \mathrm{~km}$ in the Carboniferous in the UK, based upon Figure 2. This value is similar to the modern-day value of 20-25 km, based upon the well-constrained depths of recent earthquakes (Baptie, 2010).

\section{The forces exerted between mountain ranges} and lowlands

It has been previously described how the force exerted between an isostaticallycompensated mountain range and the adjacent lowlands can be calculated by summing the lateral differences in the vertical normal stress between the two lithospheric columns (e.g. Artyushkov, 1973; Dalmayrac and Molnar, 1981). 
It is important to consider density differences resulting from both the thermal structure of the lithosphere and also chemical depletion (e.g. England and Houseman, 1989; Molnar et al., 1993). We have built upon this prior work by calculating the force exerted between a mountain range and an adjacent lowland using a wide range of plausible parameters, in order to estimate the range of possible force magnitudes.

In our calculations we enforce isostatic compensation at the base of the lithosphere, and assume that lithosphere thickness contrasts occur in proportion to crustal thickness contrasts (as has recently shown to be the case in present-day Asia; $\mathrm{M}^{\mathrm{c}}$ Kenzie and Priestley (2016)). We vary the crustal thickness in the mountains from 55 to $80 \mathrm{~km}$ (the values of all the parameters used in our calculations are given in Table 1). The density reduction caused by the chemical depletion of the lithosphere relative to the asthenosphere is taken to be $60 \mathrm{~kg} / \mathrm{m}^{3}$, based upon geochemical results from Tibet and Iran (McKenzie and Priestley, 2016). The crustal thickness in the lowlands has been varied from $32-36 \mathrm{~km}$, based on receiver functions and seismic experiments in the UK (Davis et al., 2012). We take the lithosphere thickness in the lowlands to be $120 \mathrm{~km}$ (McKenzie and Priestley, 2016). We have used 
densities for the crust and lithospheric mantle at the Earth's surface of 2800 and $3330 \mathrm{~kg} / \mathrm{m}^{3}$, have used a thermal expansion coefficient of $3 \times 10^{-5}$ for the crust, and the expressions of Bouhifid et al. (1996) for the temperaturedependence of density in the mantle (assumed to be dominated by olivine). In the lowlands we assume that the geotherm is in steady-state, which we approximate as linear gradients in the crust and mantle. The temperature at the base of the lithosphere is enforced to be the isentropic temperature at that depth (calculated for a mantle potential temperature of $1315^{\circ}$ ). We have varied the temperature of the Moho in the lowlands between $600^{\circ} \mathrm{C}$ and $700^{\circ} \mathrm{C}$, which spans the range commonly suggested for regions with a similar crust and lithosphere thickness to the UK (e.g. Emmerson et al., 2006; Copley et al., 2009). In the mountains we use the shape of the geotherms calculated for southern Tibet by Craig et al. (2012), which take into account the advection of heat caused by underthrusting on the margins of mountain ranges. We scale these geotherms to match the thickness of the crust in the mountains, and to vary the temperature at the Moho between $600^{\circ} \mathrm{C}$ and $800^{\circ} \mathrm{C}$ (which encompasses inferences from modern-day orogenic belts, based upon thermal models and the distribution of lower-crustal earthquakes (e.g. Craig et al., 2012)). 
We have computed the magnitude of the force exerted between the mountains and the lowlands for all combinations of these parameter ranges. Figure 3 shows the number of models that predict each value of the force, as a function of the crustal thickness in the mountains. The thick dashed black line shows the values obtained by assuming isostatic compensation at the base of the crust, and constant densities for the crust and mantle, which over-estimates the magnitude of the force. Support for our calculations is provided by the independent estimates of the crustal thickness in Tibet (7580 km, e.g. Mitra et al., 2005), and the force exerted between India and Tibet $\left(5.5 \pm 1.5 \times 10^{12} \mathrm{~N} / \mathrm{m}\right.$; Copley et al., 2010), which is in the range predicted by our calculations (Figure 3). Pressure-temperature estimates from high-grade crustal metamorphic rocks from central Europe imply that the crust in the Variscan mountains was 65-73 km thick (e.g. Kroner and Romer, 2013, and references therein), so Figure 3 suggests that the force exerted between these mountains and their foreland in the northern UK was $1-6 \times 10^{12} \mathrm{~N}$ per metre along-strike. The inset on Figure 3 shows the relative likelihood of each force value, based upon how many of the combinations of the adjustable parameters result in each estimated value. 


\section{$5 \quad$ Fault strength}

We can estimate an upper bound on the shear stresses that caused the faults in the Variscan foreland to slip, by assuming that all of the force estimated above is supported by the seismogenic layer. Detailed mapping of the late Carboniferous shortening suggests that the motion was accommodated on structures striking between $45^{\circ}$ and $90^{\circ}$ from the maximum compression direction (e.g. Corfield et al., 1996; Woodcock and Rickards, 2003; Warr, 2012). In common with modern-day thrusts from regions of reactivated normalfaulting, and mapping of Variscan-age faults in our region of interest, we vary the dip of the faults over the range $45-70^{\circ}$ (e.g. Sibson and Xie, 1998; Woodcock and Rickards, 2003). We have conducted calculations to resolve the total force exerted between the mountains and the lowlands onto the foreland faults, using the method of Lamb (2006). This method balances the forces exerted on the wedge of material overlying a fault, and includes both the tectonic stresses and gravity acting on the mass of the rock. Because the seismogenic thickness we estimate is smaller than, or similar to, the crustal 
thickness, we use only a single fault rheology (rather than using different parameters to represent the crustal and mantle, as done by Lamb (2006)). We use the range of fault strikes and dips described above, along with the range of possible seismogenic thickness estimated above, and the distribution of estimated forces shown in the inset on Figure 3. Our results for the maximum shear stresses supported by the faults are shown in Figure 4. The maximum shear stress is most likely to be in the range 10-100 MPa (which encompasses $90 \%$ of the models), with a nominal most likely value of $37.5 \mathrm{MPa}$. The corresponding upper bound on the effective coefficient of friction when these faults slipped is most likely to be in the range $0.02-0.24$ (which encompasses $90 \%$ of the models), with a nominal most likely value of 0.08 . This range is considerably lower than predicted by 'Byerlee's Law' (i.e. 0.6-0.8). For the faults to have slipped in response to the calculated force implies intrinsically weak fault rocks in the reactivated fault zones, high pore fluid pressures, or both. If some of the force transmitted through the Variscan foreland was supported by stresses in the ductile lithosphere, then the faults would be weaker than estimated here. In addition, the above analysis implicitly assumes that the deviatoric stresses in the Variscan Mountains are minor, and that the majority of the force calculated above is supported by 
the lithosphere in the foreland of the range. However, if significant stresses are supported elsewhere, e.g. by driving the viscous flow of the mountains over the underthrusting foreland, then the faults would be weaker than our estimate.

A striking feature of the late Carboniferous shortening in the northern UK is that many structures were active at an oblique angle to the maximum shortening direction (Figure 1). The faults that have been studied in detail (e.g. the Dent Fault; Woodcock and Rickards (2003); Thomas and Woodcock (2015); labelled on Figure 1) were pre-existing structures that were re-activated in the late Carboniferous. Fault motion at an oblique angle is less energetically-favourable than motion on an optimally-oriented fault (i.e. perpendicular to the shortening direction, and with a dip that is optimum for the coefficient of friction). We can estimate how much weaker these preexisting faults must be than optimally oriented, but un-faulted, planes by resolving forces in these two configurations. Specifically, we resolve the total force estimated above onto planes with the dips and orientations observed in the northern UK, and onto faults that strike perpendicular to the maximum principal stress and dip at angles optimum for their coefficient of friction. 
257 The differences in resolved stresses in these two geometries allow us to in${ }_{258}$ fer how much weaker pre-existing faults must be than intact rock, in order 259 for reactivation to have occurred, rather than the formation of new faults. ${ }_{260}$ We find that the re-activated structures must have an effective coefficient of

\section{${ }_{264} 6$ Conclusions}

\section{Conclusions} than un-faulted rock. friction at least $30 \%$ lower than intact rock in order for them to have been reactivated, rather than new faults initiating.

We have described how to estimate the seismogenic thickness in ancient deformation belts, and have estimated the forces exerted between mountain ranges and lowlands by including thermal and chemical effects on the density. Combining these results for the deformation in the foreland of the Variscan Mountains in the northern UK shows that the faults had a low effective coefficient of friction (i.e. $0.02-0.24$ ), and were at least $30 \%$ weaker 


\section{${ }_{273} 7 \quad$ Acknowledgements}

We thank Simon Lamb and one anonymous reviewer for helpful comments on the manuscript, and the participants in the 2015 Cambridge Earth Sciences field trip to Sedbergh for stimulating discussions. This work forms part of the NERC- and ESRC-funded project 'Earthquakes without Frontiers', and was partially supported by the NERC grant 'Looking Inside the Continents from Space'.

\section{References}

N. Aitkenhead, W.J. Barclay, A. Brandon, R.A. Chadwick, M.J.I. Chisholm, A.H. Cooper, and E.W. Johnson. British Regional Geology: the Pennines and adjacent areas (4th edition). HMSO, London, 2002.

B.P. Allmann and P.M. Shearer. Global variations of stress drop for moderate to large earthquakes. J. Geophys. Res., 114:doi:10.1029/2008JB005821, 2009.

E.V. Artyushkov. Stresses in the lithosphere caused by crustal thickness inhomogeneities. J. Geophys. Res., 78:7675-7708, 1973.

M. Assumpcao. The regional intraplate stress field in South America. J. Geophys. Res., 97:11,889-11,903, 1992.

B. Baptie. Seismogenesis and state of stress in the UK. Tectonophysics, 482: 150-159, 2010. 
K-P. Bonjer. Seismicity pattern and style of seismic faulting at the eastern borderfault of the southern Rhine Graben. Tectonophysics, 275:41-69, 1997.

M.A. Bouhifid, D. Ardrault, G. Fiquet, and P. Richet. Thermal expansion of forsterite up to the melting point. Geophys. Res. Lett., pages 1143-1146, 1996.

British Geological Survey. Tectonic map of Britain, Ireland and adjacent areas, 1996. British Geological Survey, Nottingham.

M. Brudy, M.D. Zoback, K. Fuchs, F. Rummel, and J. Baumgartner. Estimation of the complete stress tensor to $8 \mathrm{~km}$ depth in the KTB scientific drill holes: Implications for crustal strength. J. Geophys. Res., 102:18,45318,475, 1997.

J. Byerlee. Friction of rocks. Pure. Appl. Geophys., 116:615-626, 1978.

R.A. Chadwick, D.W. Holliday, S. Holloway, and A.G. Hulbert. The structure and evolution of the Northumberland-Solway Basin and adjacent areas. British Geological Survey Subsurface Memoir, HMSO, London, 1995.

B. Cheng, S. Cheng, G. Zhang, and D. Zhao. Seismic structure of the HelanLiupanOrdos western margin tectonic belt in north-central China and its geodynamic implications. Journal of Asian Earth Sciences, 87:141-156, 2014.

C. Collettini and R.H. Sibson. Normal faults, normal friction? Geology, 29: 927-930, 2001.

A. Copley, F. Boait, J. Hollingsworth, J. Jackson, and D. McKenzie. Subparallel thrust and normal faulting in Albania and the role of gravitational potential energy and rheology contrasts in mountain belts. J. Geophys. Res., 114:doi:10.1029/2008JB005931, 2009.

A. Copley, J-P. Avouac, and J-Y. Royer. The India-Asia collision and the Cenozoic slowdown of the Indian plate: implications for the forces driving plate motions. J. Geophys. Res., 115:doi:10.1029/2009JB006634, 2010.

A. Copley, J-P. Avouac, J. Hollingsworth, and S. Leprince. The $2001 \mathrm{Mw}$ 7.6 Bhuj earthquake, low fault friction, and the crustal support of plate 
driving forces in India. J. Geophys. Res., 116:doi:10.1029/2010JB008137, 2011.

S.M. Corfield, R.L. Gawthorpe, M. Gage, A.J. Fraser, and B.M. Besley. Inversion tectonics of the Variscan foreland of the British Isles. Journal of the Geological Society, 153:17-32, 1996.

T. Craig, A. Copley, and J. Jackson. Thermal and tectonic consequences of india underthrusting tibet. Earth Planet. Sci. Lett., 353-354:231-239, 2012 .

T. Craig, A. Copley, and T. Middleton. Constraining fault friction in oceanic lithosphere using the dip angles of newly-formed faults at outer rises. Earth Planet. Sci. Lett., 392:94-99, 2014.

T.J. Craig, J.A. Jackson, K. Priestley, and D. McKenzie. Earthquake distribution patterns in Africa: their relationship to variations in lithospheric and geological structure, and their rheological implications. Geophys. J. Int., 185:403-434, 2011.

B. Dalmayrac and P. Molnar. Parallel thrust and normal faulting in Peru and constraints on the state of stress. Earth Planet. Sci. Lett., 55:473-481, 1981.

M.W. Davis, N.J. White, K.F. Priestley, B.J. Baptie, and F.J. Tilmann. Crustal structure of the British Isles and its epeiogenic consequences. Geophys. J. Int., 190:705-725, 2012.

B. Emmerson, J. Jackson, D. McKenzie, and K. Priestley. Seismicity, structure, and rheology of the lithopshere in the Lake Baikal region. Geophys. J. Int., 167:1233-1272, 2006.

P. England and G. Houseman. Extension during continental convergence, with application to the Tibetan plateau. J. Geophys. Res., 94:17561-17579, 1989 .

D. Hatzfeld, A.A. Christodoulou, E.M. Scordilis, D. Panagiotopoulos, and P.M. Hatzidimitriou. A microearthquake study of the Mygdonian graben (northern Greece). Earth Planet. Sci. Lett., 81:379-396, 1987. 
D. Hatzfeld, V. Karakostas, M. Ziazia, I. Kassaras, E. Papadimitriou, K. Makropoulos, N. Voulgaris, and C. Papaioannou. Microsesmicity and faulting geometry in the Gulf of Corinth (Greece). Geophys. J. Int., 141: 438-456, 2000.

G.A. Ichinose, J.G. Anderson, K.G. Smith, and Y. Zeng. Source parameters of Eastern California and Western Nevada earthquakes from regional moment tensor inversion. Bull. Seismol. Soc. Am., 93:61-84, 2003.

J. A. Jackson and N. J. White. Normal faulting in the upper continental crust: Observations from regions of active extension. J. Struct. Geol., 11: 15-36, 1989.

E. Jacques, J.C. Ruegg, J.C. Lepine, P. Tapponnier, G.C.P. King, and A. Omar. Relocation of M>2 events of the 1989 Dobi seismic sequence in Afar: evidence for earthquake migration. Geophys. J. Int., 138:447469, 1999.

H. Kanamori and D.L. Anderson. Theoretical basis of some empirical relations in seismology. Bull. Seismol. Soc. Am., 65:1073-1095, 1975.

U. Kroner and R.L. Romer. Two plates - many subduction zones: The Variscan orogeny reconsidered. Gondwana Research, 24:298-329, 2013.

S. Lamb. Shear stresses on megathrusts: Implications for mountain building behind subduction zones. J. Geophys. Res., 111: doi:10.1029/2005JB003916, 2006.

X. Liang, S. Zhou, Y.J. Chen, G. Jin, L. Xiao, P. Liu, Y. Fu, Y. Tang, X. Lou, and J. Ning. Earthquake distribution in southern Tibet and its tectonic implications. J. Geophys. Res., 113:doi:10.1029/2007JB005101, 2008.

D.A. Lockner, C. Morrow, D. Moore, and S. Hickman. Low strength of deep San Andreas fault gouge from SAFOD core. Nature, 472:82-85, 2011.

D. McKenzie and K. Priestley. Speculations on the formation of cratons and cratonic basins. Earth Planet. Sci. Lett., 435:94-104, 2016.

T.A. Middleton and A. Copley. Constraining fault friction by re-examining earthquake nodal plane dips. Geophys. J. Int., 196:671-680, 2014. 
S. Mitra, K. Priestley, A.K. Bhattacharyya, and V.K. Gaur. Crustal structure and earthquake focal depths beneath northeastern India and southern Tibet. Geophys. J. Int., 160:227-248, 2005.

P. Molnar, P. England, and J. Martinod. Mantle dynamics, uplift of the Tibetan plateau, and the Indian monsoon. Reviews of Geophysics, 31: 357-396, 1993.

W.D. Richins, J.C. Pechmann, R.B. Smith, C.J. Langer, S.K. Goter, J.E. Zollweg, and J.J. King. The 1983 Borah Peak, Idaho, earthquake and its aftershocks. Bull. Seismol. Soc. Am., 77:694-723, 1987.

A. Rigo, H. Lyon-Caen, R. Armijo, A. Deschamps, D. Hatzfeld, K. Makropoulos, P. Papadimitriou, and I. Kassaras. A microseismic study in the Gulf of Corinth (Greece): Implications for large-scale normal faulting mechanisms. Geophys. J. Int., 126:663-688, 1996.

C. H. Scholz and J. C. Contreras. Mechanics of continental rift architecture. Geology, 26:967-970, 1998.

R.H. Sibson and G. Xie. Dip range for intracontinental reverse fault ruptures: Truth not stranger than friction? Bull. Seismol. Soc. Am., 88:1014-1022, 1998.

A.M. Stein and D.J. Blundell. Geological inheritance and crustal dynamics of the northwest Scottish continental shelf. Tectonophysics, 173:455-467, 1990 .

C.W. Thomas and N.H. Woodcock. The kinematic linkage of the Dent, Craven, and related faults of Northern England. Proceedings of the Yorkshire Geological Society, 60:258-274, 2015.

J. Townend and M.D. Zoback. How faulting keeps the crust strong. Geology, 28:399-402, 2000.

K. Ujiie, H. Tanaka, T. Saito, A. Tsutsumi, J.J. Mori, J. Kameda, E.E. Brodsky, F.M. Chester, N. Eguchi, S. Toczko, Expedition 343, and 343T Scientists. Low coseismic shear stress on the Tohoku-Oki megathrust determined from laboratory experiments. Science, 342:1211-1214, 2013. 
K. Vanneste, T. Camelbeeck, and K. Verbeek. A model of composite seismic sources for the Lower Rhine Graben, northwest Europe. Bull. Seismol. Soc. Amer., 103:984-1007, 2013.

L.N. Warr. The Varican orogeny: the welding of Pangaea. In N. Woodcock and R. Strachan, editors, Geological history of Britain and Ireland. WileyBlackwell, 2012.

C.N. Waters and S.J. Davies. Carboniferous: extensional basins, advancing deltas and coal swamps. In P.J. Brenchley and P.F. Rawson, editors, The geology of England and Wales, 2nd edition. The Geological Society, London, 2006.

N. Woodcock and R. Strachan. Geological history of Britain and Ireland. Wiley-Blackwell, 2012.

N.H. Woodcock and B. Rickards. Transpressive duplex and flower structure: Dent fault system, NW England. Journal of Structural Geology, 25:19811992, 2003. 


\section{Adjusted parameters:}

\begin{tabular}{ccc}
\hline Parameter & $\begin{array}{c}\text { minimum } \\
\text { value }\end{array}$ & $\begin{array}{c}\text { maximum } \\
\text { value }\end{array}$ \\
\hline Seismogenic thickness in lowlands $(\mathrm{km})$ & 15 & 40 \\
Crustal thickness in mountains $(\mathrm{km})$ & 55 & 80 \\
Crustal thickness in lowlands $(\mathrm{km})$ & 32 & 36 \\
Moho temperature in mountains $\left({ }^{\circ} \mathrm{C}\right)$ & 600 & 800 \\
Moho temperature in lowlands $\left({ }^{\circ} \mathrm{C}\right)$ & 600 & 700 \\
Fault strike w.r.t. max. principal stress & $45^{\circ}$ & \\
Foreland fault dips & $45^{\circ}$ & \\
Fixed parameters: & & \\
Parameter & & \\
\hline Value & -60 & \\
\hline Density difference from depletion $\left(\mathrm{kg} / \mathrm{m}^{3}\right)$ & 120 & \\
Lithosphere thickness in lowlands $(\mathrm{km})$ & 2800 & \\
Crust density at $0^{\circ} \mathrm{C}\left(\mathrm{kg} / \mathrm{m}^{3}\right)$ & 3330 & \\
Lithospheric mantle density at $0^{\circ} \mathrm{C}\left(\mathrm{kg} / \mathrm{m}^{3}\right)$ & $3 \times 10^{-5}$ & \\
Thermal expansion co-eff of $\mathrm{crust}$ & Bouhifid et al. $(1996)$ & \\
Thermal expansion in mantle & $1315^{\circ} \mathrm{C}$ & \\
Mantle potential temperature & & \\
\hline
\end{tabular}

Table 1: Parameters used in the calculations. 


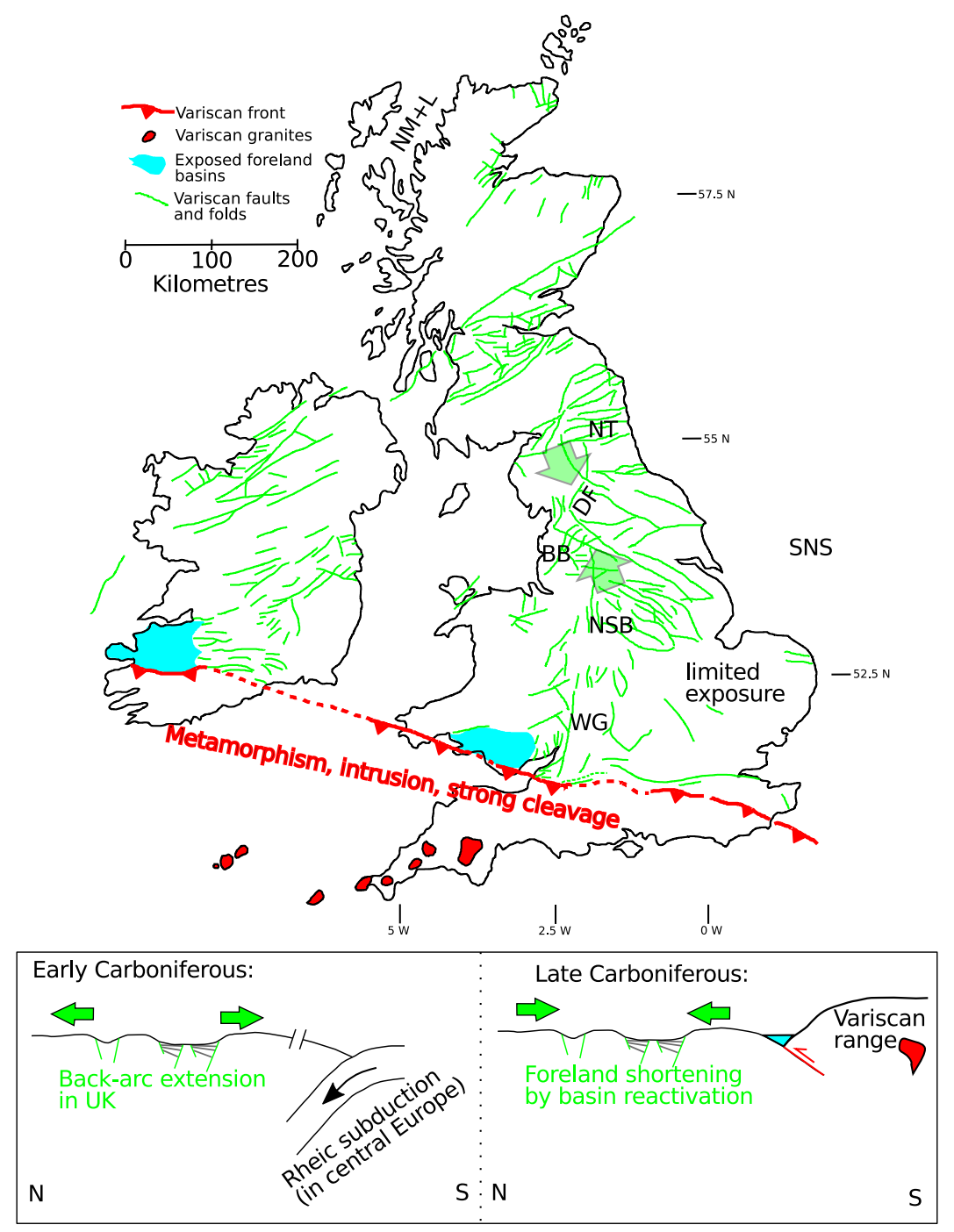

Figure 1: Summary of Variscan tectonics of the UK, adapted from Warr (2012), after British Geological Survey (1996). Metamorphism and intrusion occurred in the region to the south of the red line, which marks the Variscan range-front. Blue shading shows exposed areas of the Variscan foreland basin. Green lines show faults and folds that were active in the foreland of the Variscan mountain range. The green arrows in the centre of the map show the regional shortening direction estimated by Woodcock and Rickards (2003). DF denotes the Dent Fault. Other black labels show the locations of Carboniferous and Permian-Triassic extensional basins mentioned in the text. NM+L: North Minch and North Lewis Basins; NT: Northumberland Trough; BB: Bowland Basin; NSB: North Staffordshire Basin; WG: Worcester Graben; SNS: Southern North Sea. The lower diagrams show schematic cross-sections during early and late carboniferous times. 


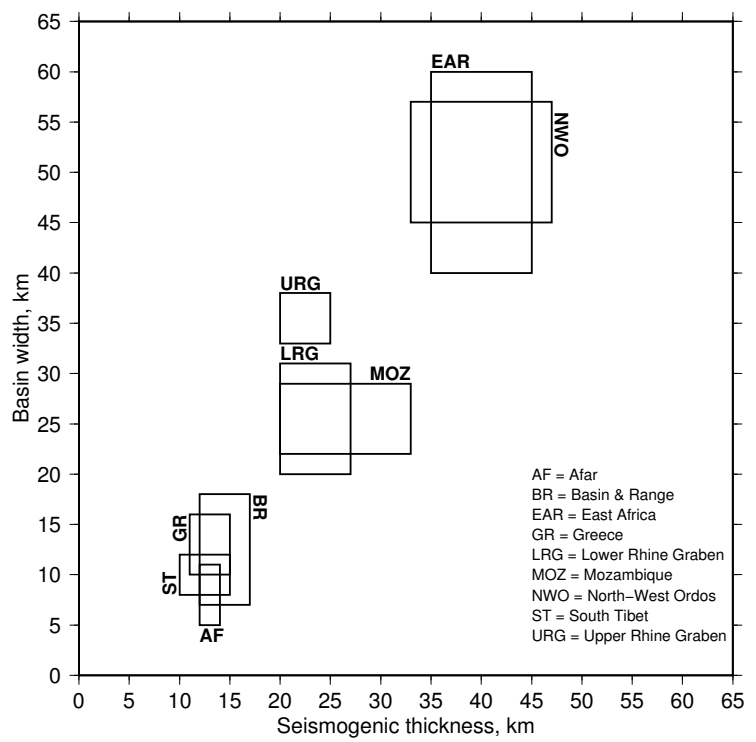

Figure 2: Relationship between the seismogenic thickness and maximum basin width for regions undergoing present-day extension. Each box represents earthquakes and basins in a different region, described in detail below. The specific areas were selected based on the availability of multiple earthquakes with well-constrained depths that clearly delimit the seismogenic thickness, and clearly-defined extensional basins. GR: the gulfs of Corinth and Evia, and Thessaloniki, Greece (Hatzfeld et al., 1987; Rigo et al., 1996; Hatzfeld et al., 2000); AF: Dobi graben, central Afar (Jacques et al., 1999); ST: central southern Tibet (Liang et al., 2008); BR: Borah Peak region, plus eastern California and western Nevada, Basin and Range, USA (Richins et al., 1987; Ichinose et al., 2003); LRG: Lower Rhine Graben (Vanneste et al., 2013); URG: Upper Rhine Graben (Bonjer, 1997); MOZ: Mozambique (Craig et al., 2011); EAR: western branch of the East African Rift (Craig et al., 2011, and references therein); NWO: north-west margin of Ordos (Cheng et al., 2014). 


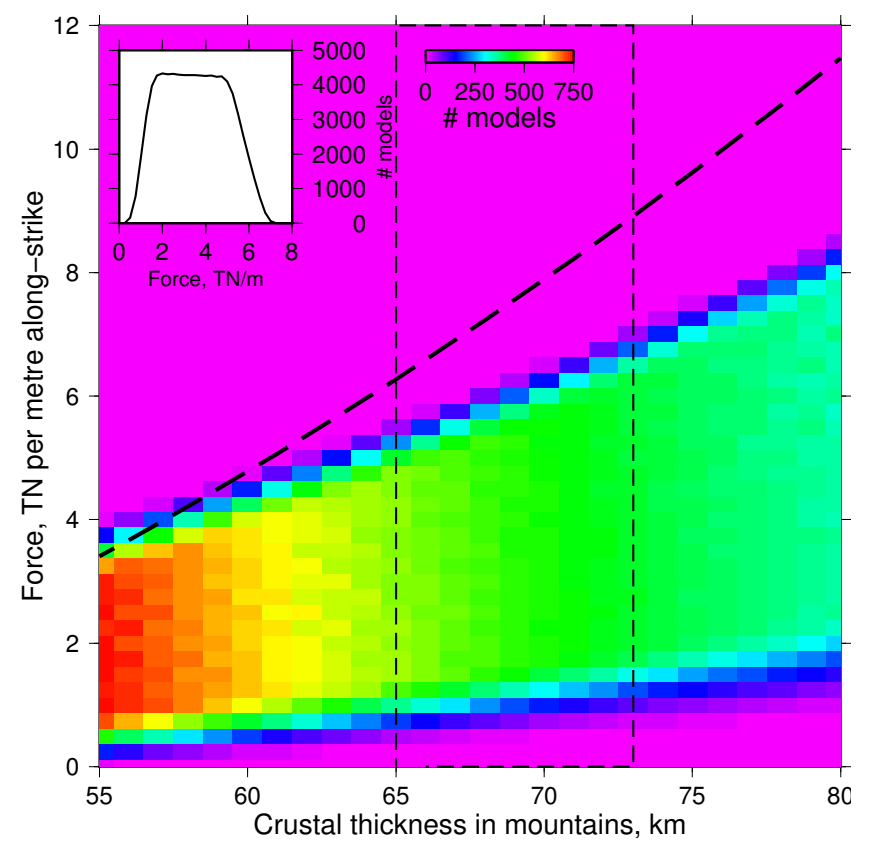

Figure 3: Distribution of forces exerted between an isostatically-compensated mountain range and the adjacent lowlands, calculated using the range of parameters described in the text. The main figure shows the number of models that predict each value of the force, as a function of the crustal thickness in the mountains. The inset shows the distribution of model results for all values of the crustal thickness in the mountains from 65 to $73 \mathrm{~km}$, marked by the thin dashed lines on the main Figure. The thick dashed line shows the force calculated assuming isostatic compensation at the base of the crust and constant densities of 2800 and $3300 \mathrm{~kg} / \mathrm{m}^{3}$ for the crust and mantle. 

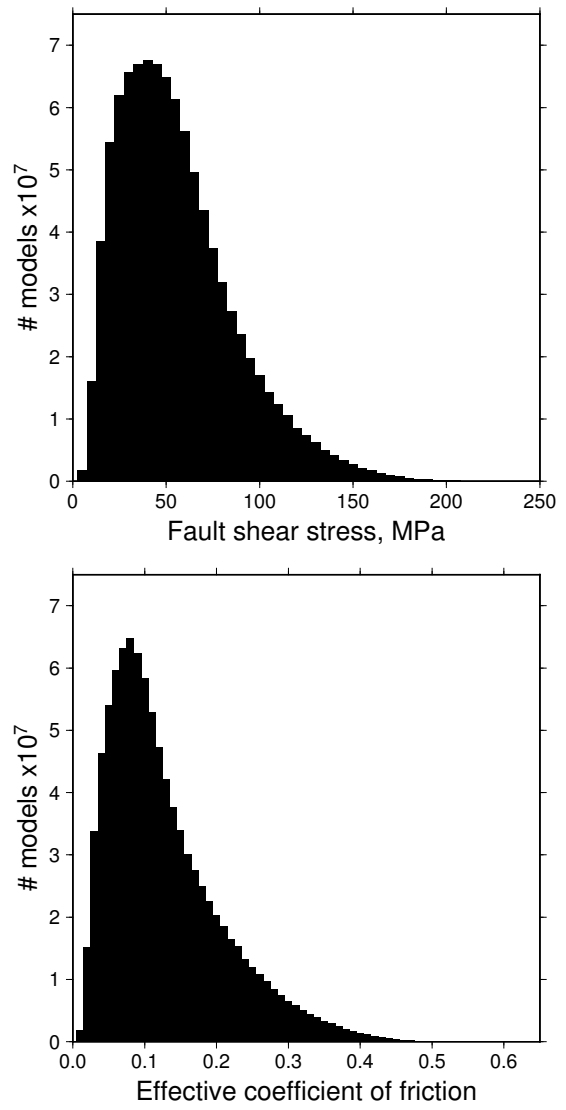

Figure 4: Estimates of the maximum possible fault shear stress (top) and effective coefficient of friction (bottom) in the Variscan foreland of the northern UK, based on the ranges of parameters described in the text. 